\title{
EFFECT OF TEMPERATURE AND EXCESS AIR RATIO ON COMBUSTION PROCESS OF MIXTURES OF ERUCIC RAPESEED
}

\begin{abstract}
Adam KUPCZYK, Department of Production Management and Engineering, Warsaw University of Life Sciences - SGGW, Nowoursynowska str. 164, 02-787 Warszawa. Poland. adam kupczyk@ sggw.pl (corresponding author)

Karol TUCKI, Department of Organization and Production Engineering, Faculty of Production Engineering, Warsaw University of Life Sciences - SGGW, Nowoursynowska str. 164,02-787 Warszawa. Poland. karol_tucki@sggw.pl

The paper presents results of investigations into diesel engine fuelled with high erucic acid rapeseed oil and its mixture with diesel, petrol and ethanol at different proportions. The study was performed in a chamber with constant volume depending on temperatu re and air pressure and the coefficient of excess air. The main purpose of performed tests was to determine the effect of various parameters on processes of spontaneous combustion and combustion of fuels. During the study basic parameters of combustion, e.g. auto-ignition delay, greatest pressure and contractual time were compared. Studies show that increased pressure injection improves combustion process for all test fuels, and injection pressure most strongly affect the combustion process of rapesee $\mathrm{d}$ oil and its mixtures with ethanol.
\end{abstract}

Keywords: combustion, erucic, excess air ratio, rapeseed, temperature

\section{INTRODUCTION}

As presently the concept of sustainable development is being developed and non-renewable raw materials for energy needs are becoming gradually depleted, it may be presumed that agriculture may contribute to reduction of $\mathrm{CO}_{2}$ emission (Ashraful et. al, 2014). This sector is capable of supplying raw materials for the production of biofuels, in such a way implementing EU legal requirements. In the European Union among others rapeseed oil is used for the production of biodiesel (Czaban et. al, 2015; Osiak at. al, 2013). The usage of plant oil as engine fuel allows achieving numerous advantages, such as diversification of income and reduction of $\mathrm{CO}_{2}$ emission. The chemical and physical properties of oils allow their usage in diesel engines (Buyukkaya et. al, 2014; Mahmudul et. al, 2017). Approximately $15 \%$ of those oils being used worldwide for energy needs are obtained from rapeseed, especially in Europe (BełdyckaBórawska et. al, 2015; Dyrektywa). Given the constantly growing area of cultivations to be used for energy-related needs, the emission caused by ILUC became a topic for talks pertaining among others to the future of conventional biofuels (of the first generation). For this reason the use of advanced biofuels obtained from waste and other remnants is being promoted (Jabłońska, 2014).

The objective of the studies was to perform a qualitative assessment of the impact exerted by temperature and the excess air coefficient in the chamber on the combustion process of petrol and ethanol.

The combustion process was studied for four air temperatures: $350^{\circ} \mathrm{C}, 425^{\circ} \mathrm{C}, 500^{\circ} \mathrm{C}$ and $575^{\circ} \mathrm{C}$ and for three air pressure values in the chamber: 0.5 $\mathrm{MPa}, 0.7 \mathrm{MPa}$ and $0.9 \mathrm{MPa}$. The dose of fuel and injection pressure underwent changes - $65 \mathrm{MPa}, 100 \mathrm{MPa}, 135 \mathrm{MPa}$.

\section{METHODOLOGY ADOPTED FOR ANALYSIS}

The studies were carried out on a stand furnished with the following systems: fuel supply (Common Rail) with electronic control of multi-phase injection, control of injection time, process recording, air supply, measurement of combustion pressure in the chamber and additional assemblies (illuminators, vacuum pump). Study chambers enabled the visualisation of processes of injection and combustion, and also heating the agent within the temperature range of $400-700^{\circ} \mathrm{C}$. The control system permitted changing the size of pilot dose and elementary dose in the initial phase of injection, the time interval between doses and pressure at injection start. In paper we examined the following fuels: diesel (ON100\%), erucic rapeseed oil (R100\%) and their mixtures with unleaded gas (U) $(70 \% \mathrm{R}+\mathrm{U} 30 \%, 85 \% \mathrm{R}+$ $15 \% \mathrm{U})$ and ethanol $(70 \% \mathrm{R}+\mathrm{E} 30 \%, 85 \% \mathrm{R}+15 \% \mathrm{E})$.

Copyright (C) 2017 The Authors. Published by Aleksandras Stulginskis University. This is an open-access article distributed under the terms of the Creative Commons Attribution License (CC-BY 4.0), which permits unrestricted use, distribution, and reproduction in any medium, provided the original author and source are credited. 


\section{RESULTS}

At a temperature of $350^{\circ} \mathrm{C}$ (Fig. 1) the combustion rate of a mixture of rapeseed oil with an addition of $15 \%$ and $30 \%$ of U95 petrol was very low, much lower than that for diesel. At the highest air temperature of $575^{\circ} \mathrm{C}(\mathrm{Fig} .2)$ combustion progress of rapeseed oil and diesel is similar. Differences in maximum values of combustion pressure arise from a difference in calorific value. The addition of light fractions shortens the delay of self-ignition, but also tend to impair their further combustion.

The delay period of self-ignition for rapeseed oil and diesel at low temperatures differed considerably (Fig. 3). At high temperatures the differences were similar for both rapeseed oil and diesel with mixtures. If temperature grew, the quickest shortening of the self-ignition period took place of mixtures with petrol.

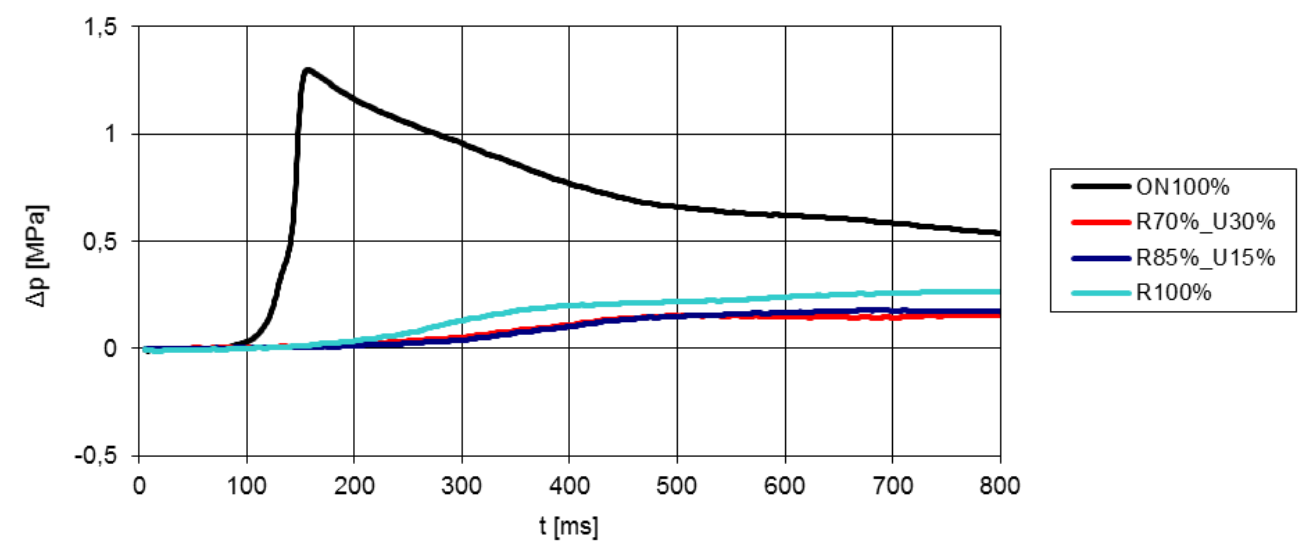

Figure 1. Increase in combustion pressure in the chamber; Initial temperature $350^{\circ} \mathrm{C}$; Initial pressure $0.7[\mathrm{MPa}]$; Injection pressure $100[\mathrm{MPa}] ; \lambda=2.5$

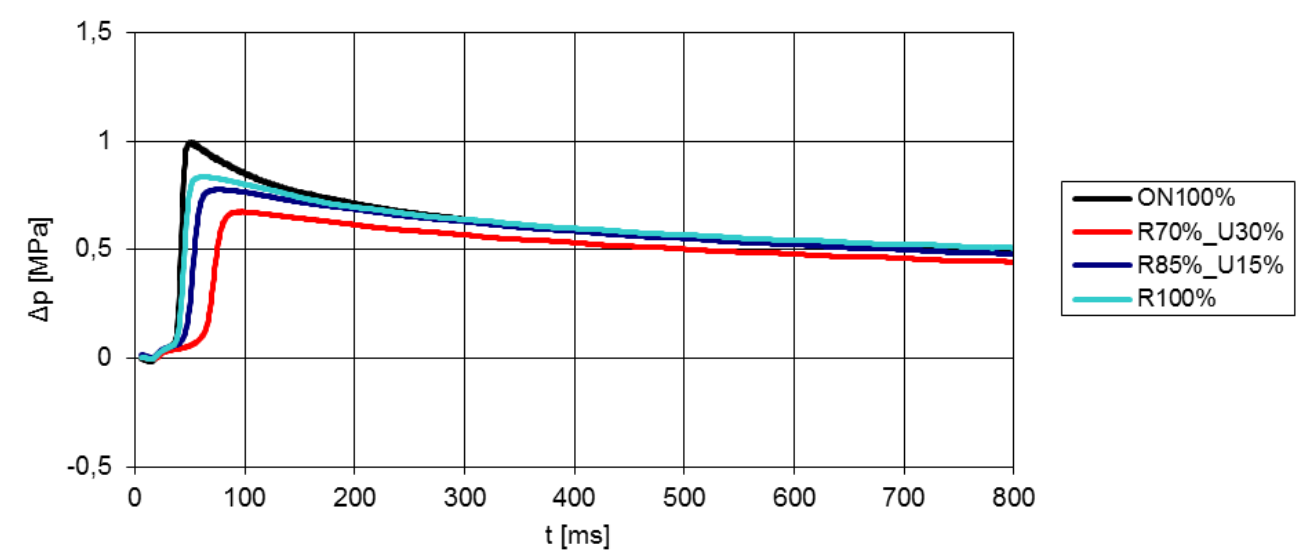

Figure 2. Increase in combustion pressure in the chamber; Initial temperature $575^{\circ} \mathrm{C}$; Initial pressure 0.7 [MPa]; Injection pressure $100[\mathrm{MPa}] ; \lambda=2.5$

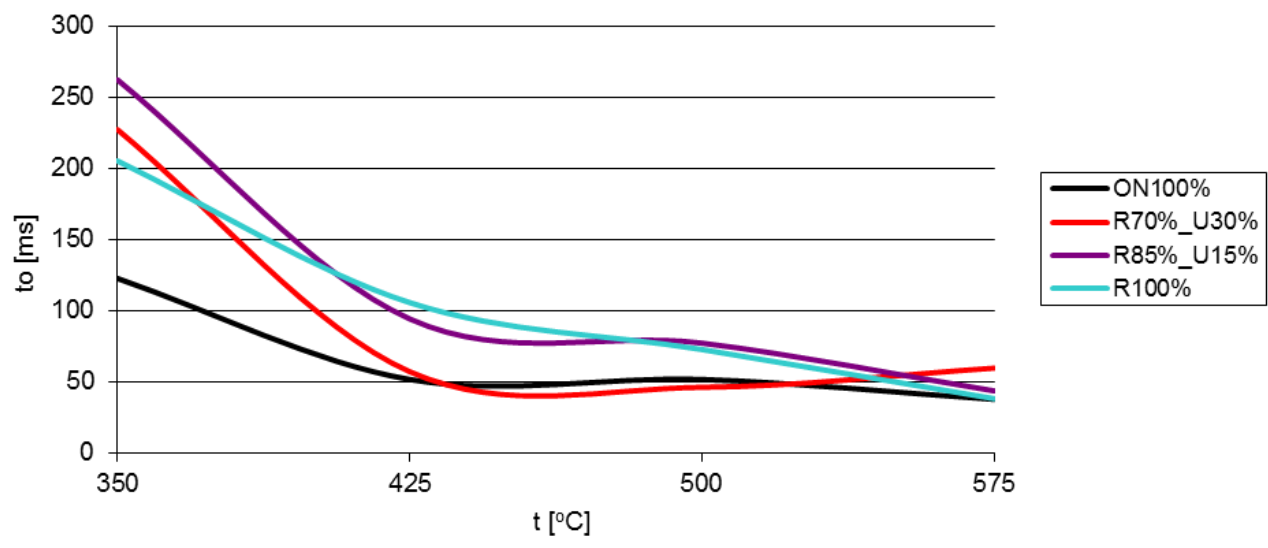

Figure 3. The impact of mixture of oil and gasoline on the auto-ignition delay time; Initial temperature $350^{\circ} \mathrm{C}$; The initial pressure $0.7[\mathrm{MPa}]$; Injection pressure $100[\mathrm{MPa}] ; \lambda=2,5$ 
Similarly as for combustion of a mixture of rapeseed oil with petrol. air temperature in the chamber also has a significant impact on the combustion process of a mixture of rapeseed oil with ethanol. At low temperatures (Fig. 4, Fig. 5) during the combustion of a mixtures of rapeseed oil with an addition of 15 and $30 \%$ progressed very slowly as compared to diesel. Delay in self-ignition of a mixture with ethanol was bigger than with rapeseed oil, despite the additions of ethanol.

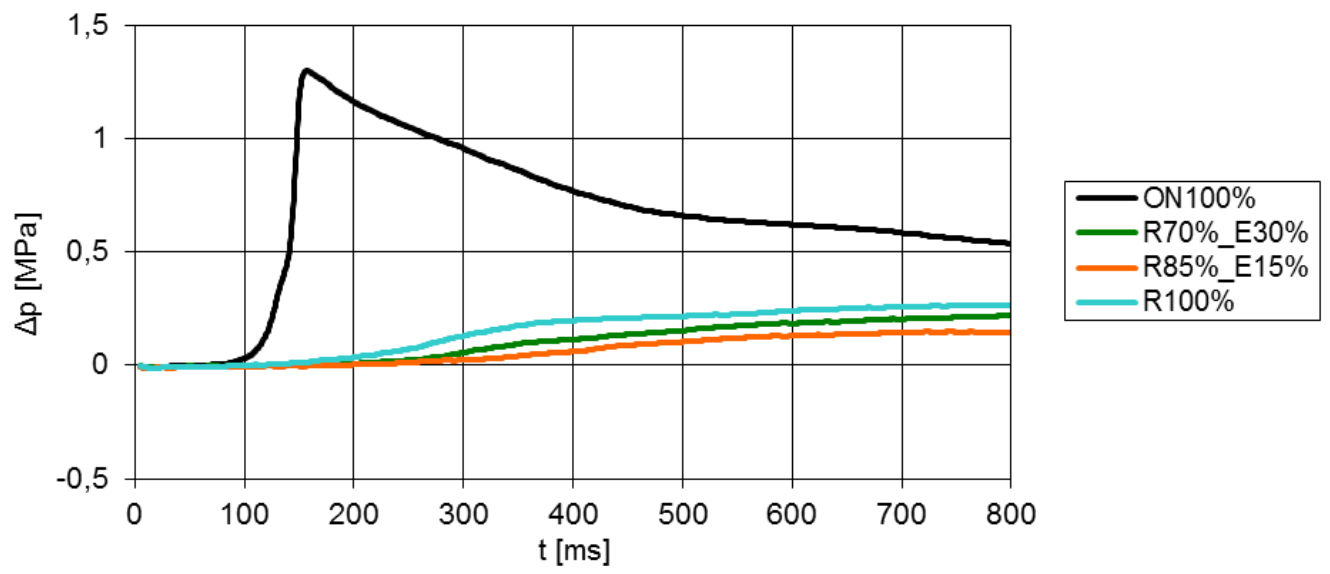

Figure 4. Increase the combustion pressure in the chamber; Initial temperature $350^{\circ} \mathrm{C}$; The initial pressure 0.7 [MPa]; Injection pressure $100[\mathrm{MPa}] ; \lambda=2,5$

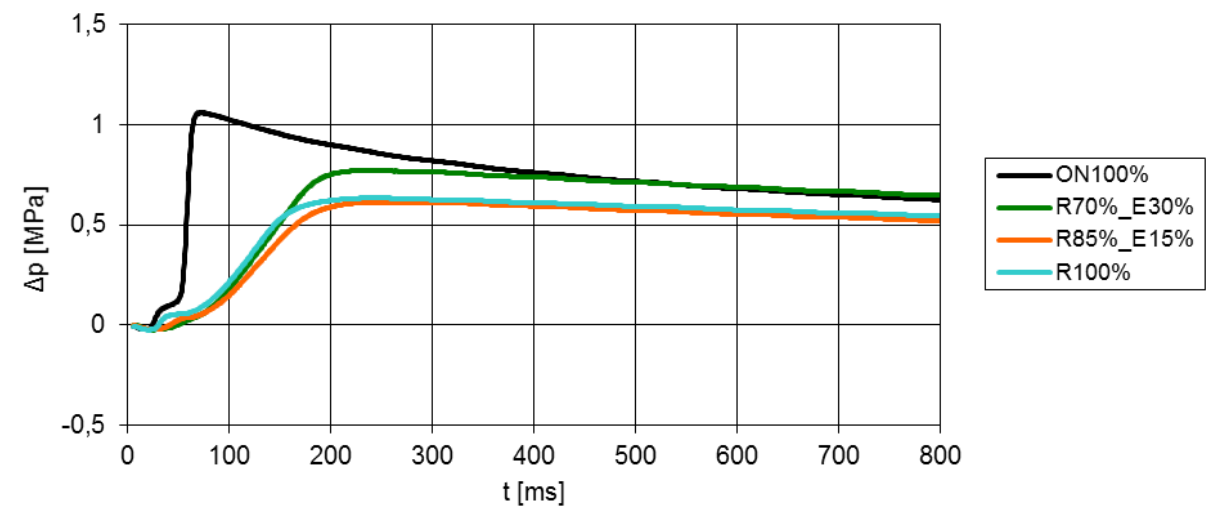

Figure 5. Increase the combustion pressure in the chamber; Initial temperature $500^{\circ} \mathrm{C}$; The initial pressure $0.7[\mathrm{MPa}]$; Injection pressure $100[\mathrm{MPa}] ; \lambda=2,5$

The conducted studies have shown that the combustion process of rapeseed oil and its mixtures with ethanol achieves parameters of the combustion process as for diesel only once the temperatures are high. The addition of ethanol has no significant impact on shortening the delay in self-ignition, beyond the scope of temperatures when the highest combustion pressure does not occur.

Currently the share of energy generated from biofuels made of cereals, other high-starch plants, plants used for sugar production and oil plants as well as plants cultivated for energy-related needs on agricultural areas as main cultivations, is to be limited to $7 \%$ of final energy use in the transport sector up to 2020. This implies a reduced importance of first generation fuels and a decrease in their share in transport, and concurrently intensified use of advanced biofuels.

\section{CONCLUSIONS}

The following conclusions have been drawn from the executed studies:

1. for all studied fuels the increase in injection pressure allows achieving an improvement in the combustion process;

2. injection pressure exerts the biggest influence on the combustion process of rapeseed oil and its mixtures with ethanol;

3. an increase in the air excess coefficient causes an impairment of the combustion progress;

4. an increased fuel injection pressure assures better combustion process progress;

5. combustion of a mixture of diesel with ethanol proved to be more advantageous as compared to a mixture of rapeseed oil with petrol; 
6. the addition of ethanol and petrol caused a reduction of viscosity, density, evaporation temperatures of a mixture of those fuels as compared to rapeseed oil, with concurrent lowering of the propensity of those mixtures to autoignition.

\section{REFERENCES}

1. Ashraful, A.M., Masjuki, H.H., Kalam, M.A., Rizwanul Fattah, I.M., Imtenan, S., Shahir, S.A., Mobarak, H.M., 2014. Production and comparison of fuel properties, engine performance, and emission characteristics of biodiesel from various non-edible vegetable oils: A review. Energy Conversion and Management, Vol.. 80, pp. 202-228.

2. Bełdycka-Bórawska A., Bórawski P., Jankowski K., 2015. Price volatility in rapeseed market in Poland. Polish Association of Agricultural and Agribusiness Economists. Vol. 17, Iss. 3, pp. 37-43. [In Polish]

3. Buyukkaya, E, Soyhan, H.S., Gokalp, B., 2014. Effects of rapeseed oil addition to a diesel fuel on thermodynamic efficiencies. International Journal of Exergy, Vol. 14, Iss. 1, pp. 101-124. 10.1504/IJEX.2014.059515

4. Czaban, J., Szpica, D., Weresa, E., Banaszuk, P., 2015. Fuel exploitation properties of diesel and vegetable oil mixtures. Combustion Engines, Vol. 162(3), pp. 335-340.

5. Dyrektywa Parlamentu Europejskiego i Rady 2015/1513 z dnia 9 września 2015 r. zmieniająca dyrektywę 98/70/WE odnoszącą się do jakości benzyny i olejów napędowych oraz zmieniającą dyrektywę 2009/28/WE w sprawie promowania stosowania energii ze źródeł odnawialnych. [In Polish]

6. Jabłońska, M., 2014, Ocena wpływu wdrożenia koncepcji ILUC na rozwój przemysłu biopaliw, Nafta-Gaz 4, s. 243-255. [In Polish]

7. Mahmudal, H.M., Hagos, F.Y., Mamat, R., Abdul, A., Ishak, W.F., Alenezi, R. 2017. Production, characterization and performance of biodiesel as an alternative fuel in diesel engines - a review. Renewable and Sustainable Energy Reviews. Vol.72, pp. 497-509. https://doi.org/10.1016/j.rser.2017.01.001

8. Osiak, J., Klimkiewicz, M., Mruk, R., Roszkowski, H., Słoma, J., Wojdalski, J. 2013. Impact of rapeseed oil cold extraction in a screw press on the selected physical and chemical properties of a product as engine fuel. Agricultural Engineering. Vol. 2 (143), pp. 253-261. [In Polish] 